\title{
Voice and silence as immediate consequences of job insecurity
}

Kimberley Breevaart

Department of Psychology, Education and Child Studies, Erasmus Universiteit Rotterdam, Rotterdam, The Netherlands

Sergio Lopez Bohle

Departamento de Administración, Facultad de Administración y Economia, Universidad de Santiago, Santiago de Chile, Chile

Jan Luca Pletzer

Department of Psychology, Education and Child Studies,

Erasmus Universiteit Rotterdam, Rotterdam, The Netherlands, and

Felipe Muñoz Medina

Departamento de Tecnologías de Gestión, Facultad Tecnológica, Universidad de Santiago, Santiago de Chile, Chile

\begin{abstract}
Purpose - The purpose of this paper is to examine the weekly effects of job insecurity on employee voice and silence. Specifically, the authors argue that because employment fulfils important needs, employees' needs are less fulfilled when they feel that their job is at risk (i.e. high job insecurity). Consequently, the authors argue that employees engage in less voice and more silence because when employees' needs are not fulfilled, they are less committed to the organization and/or protect their personal resources.

Design/methodology/approach - The authors tested their hypotheses in a five-week long diary study among 97 employees.

Findings - The authors found that employees reported lower need fulfilment in those weeks and the week after job insecurity was higher, which, in turn, decreased employee voice and increased employee silence in those weeks and the week after.

Research limitations/implications - The study shows that feelings about one's job insecurity fluctuate from week to week and that the weekly negative effects associated with increased job insecurity can be explained from a needs fulfilment perspective. The study also highlights the importance of studying voice and silence simultaneously.

Practical implications - Managers could indirectly increase employees' voice and decrease employees' silence by reducing feelings of job insecurity to increase employees' feelings of predictability of and control over their future.

Originality/value - The authors studied short-term effects of job insecurity on both employee voice and silence, and examined need fulfilment as an underlying mechanism to explain the effects of job insecurity.
\end{abstract}

Keywords Job insecurity, Voice, Diary study, Silence, Need fulfilment

Paper type Research paper

The subjective fear of losing one's job (for reviews see De Witte, 2005; Shoss, 2017) is different from actual job loss. Yet, the consequences of this subjective fear of losing one's job seem to be as detrimental as actually losing one's job (e.g. Dekker and Schaufeli, 1995; Latack and Dozier, 1986). Whereas relatively stable differences between individuals in the extent to which they feel insecure about their job result from relatively stable individual differences, such as one's personality (Debus et al., 2014; Låstad et al., 2014), intra-individual fluctuations in feelings of job insecurity are likely to have situational antecedents such as rumors or inconsistent communications (Brashers, 2001; DiFonzo and Bordia, 1998). As a consequence, employees may worry about losing their job in one week because of rumors of a planned merger or take-over, but these worries may quickly decrease when management informs employees that they do everything they can to prevent a merger, or even be further
Immediate consequences of job insecurity

Received 10 September 2018

Revised 11 March 2019 23 July 2019

12 November 2019

Accepted 10 December 2019 
increased when management confirms these plans. In support of the idea that job insecurity fluctuates from week to week within the same person, Schreurs et al. (2015) showed that employees' in-role performance suffered in weeks in which they felt more insecure about their job, but this effect was not as strong in weeks in which employees received social support from their supervisor. To better understand the dynamic nature of job insecurity and its short-term consequences, the current study focuses on intra-individual fluctuations in job insecurity related to employee voice and silence.

Silence is a lack of voice and voice means not being silent. Yet, not voicing does not automatically imply that employees are silent. That is, there may actually not be any information to share and/or employees may not have ideas to improve ways of working (Morrison, 2011). Similarly, not withholding important information (i.e. not being silent) does not mean that one voices ideas for improvement, because there may not be any important information to withhold. Therefore, it is important to distinguish between these two constructs and to examine both simultaneously. Similar to job insecurity, voice and silence have generally been shown to result from stable individual differences such as one's personality and commitment to the organization (e.g. Farndale et al., 2011; Nikolaou et al., 2008). In the current study, we examine the dynamic nature of employee voice and silence, considering that the generation of ideas for improvement (Breevaart and Zacher, 2019; Weinberger et al., 2018) as well as the decision to voice or withhold these ideas is likely to fluctuate within individuals depending on what happens at work. That is, opportunities to voice may not always arise and whether employees use these opportunities to voice or withhold information is dependent on the dynamics of the work environment, such as leader behaviors, emotions, stress, and the belief that voice will result in the desired behavior (for a review see Morrison, 2014). For example, Barnes et al. (2015) showed that leaders are more abusive toward their employees after a night of bad sleep, which makes it unlikely for employees to voice and more likely for employees to remain silent.

Job insecurity research has mainly focused on differences between employees in the extent to which they feel insecure about their job and how that affects employee voice (for meta-analyses see Cheng and Chan, 2008; Jiang and Lavaysse, 2018; Sverke et al., 2019). Studying both between- and within-person relations is important, because the former provides information on stable individual differences, whereas the latter provides insights into within-person dynamics. In the current study, we examine intra-individual fluctuations in job insecurity, and argue that this causes unpredictability and uncontrollability of the future, thereby thwarting the fulfilment of important psychological needs, which consequently undermines employee voice and stimulates employee silence. Our study of within-person differences in job insecurity brings us closer to the process through which job insecurity may affect employee voice and silence, because we examine these relations in their spontaneous, natural context, which is at work, closely after they have happened (i.e. the end of the week).

\section{Self-determination theory}

According to self-determination theory (Deci and Ryan, 2000; Van den Broeck et al., 2008), psychological need fulfilment is an important precondition for employees to be motivated and experience optimal psychological well-being. In other words, the more employees' needs are fulfilled, the more likely they are to grow and flourish. Similarly, when the fulfilment of needs is thwarted, individuals become energy-depleted and passive and experience suboptimal wellbeing. Self-determination theory distinguishes three innate psychological needs: the need for autonomy, competence, and relatedness, and considers the fulfilment of these needs more important to explain well-being than the magnitude of these needs. The need for autonomy refers to the need for psychological freedom and a sense of volition in carrying out work (deCharms, 1968). Next, the need for competence is the need to feel effective at work (White, 1959), and last, the need for relatedness refers to the need to have meaningful relationships 
with, and to feel connected to, others at work (Baumeister and Leary, 1995). The extent to which these needs are fulfilled are subject to change, even on a daily basis (e.g. van Hooff and Geurts, 2014; Verstuyf et al., 2013). In the current study, we argue that these changes fluctuate with employees' feelings of job insecurity and are associated with fluctuations in the extent to which employees are motivated to voice or be silent.

Immediate
consequences
of job
insecurity

\section{Job insecurity and need fulfilment}

The possibility of losing one's job in the near future is a highly unattractive perspective, especially because "in most contemporary societies, a job holds the key to social integration, social participation, and recognition" (De Witte, 2005, p. 3). As such, job insecurity can be considered a job stressor that thwarts the fulfilment of employees' basic needs for a number of reasons. First, job insecurity implies unpredictability and uncontrollability of the future, meaning that one does not know what will happen in the near future, which may undermine one's sense of volition and psychological freedom and therefore, thwart the fulfilment of one's need for autonomy. Feelings of job insecurity may thwart the fulfilment of the need for competence, because the achievement of work goals becomes insecure. Next, research shows that job insecurity negatively affects employees' health and performance (for meta-analyses see Cheng and Chan, 2008; Jiang and Lavaysse, 2018; Sverke et al., 2019), which may further contribute to employees feeling less autonomous and competent at work. In addition, the feeling of your job being at risk is a subjective experience, meaning that while one employee may experience high job insecurity, his or her colleague(s) may have very different experiences. Thus, when someone experiences high job insecurity, this person may feel that his/her social contacts with colleagues, and consequently the fulfilment of his/her need for relatedness, are at risk too. Because job insecurity is a stressor (DeWitte et al., 2015; Mauno et al., 2014) that threatens employees' resources (De Cuyper et al., 2012; Jahoda, 1981), employees may become protective of their resources and invest less resources in their relationship with their colleagues when they experience high job insecurity. In support of this claim, Dekker and Schaufeli (1995) showed that as the experience of job insecurity continued, employees withdrew more and more from their job and their organization. Additionally, Breevaart and Tims (2019) showed that employees did not proactively look for social support from their colleagues on the days that they needed it when they felt that their job was at risk. Finally, job insecurity is a job stressor that increases job dissatisfaction and turnover intentions, and reduces health and performance (Cheng and Chan, 2008; Shoss, 2017; Sverke et al., 2002), and research has shown that job stressors, such as workload and emotional demands, thwart basic need fulfilment (e.g. Van den Broeck et al., 2008). Accordingly, we hypothesize that employees' need fulfilment is thwarted in the weeks that they feel more insecure about their job.

\section{Need fulfilment and employee voice and silence}

Voice refers to employees' informal communication of ideas, suggestions, concerns, information, and/or opinions to the person responsible for the specific issue (Detert and Burris, 2007; Van Dyne and LePine, 1998). By voicing, employees challenge the status quo (Van Dyne et al., 2003) and thereby try to elicit improvements and/or positive change. Contrary to voice, silence refers to withholding input that is potentially important (Morrison and Milliken, 2000; Pinder and Harlos, 2001). Compared to voice, research on silence in organizations is relatively new (Morrison and Milliken, 2000), and systematic empirical research on voice and silence is lacking (for a review see Morrison, 2014). Conceptually, one could argue that silence is similar to not voicing and voicing is similar to not remaining silent. Yet, employees who do not voice any ideas for improvement do not necessarily withhold their ideas (i.e. be silent). On the contrary, they may not have any suggestions for improvements, which means they do not voice, but they are not silent either. Another reason why research on employee voice and silence is not as integrated as they could be is that 
silence is difficult for others, such as supervisors or colleagues, to observe. When an employee does not engage in voice, (s)he may not have any ideas to voice (i.e. low voice) or may willingly withhold these ideas (i.e. silence).

We argue that when job insecurity thwarts employees' needs fulfilment at work, employees will engage in less voice and more silence. That is, when employees' needs are not fulfilled, they are less committed to their organization (Van den Broeck et al., 2010), and therefore less likely to go the extra mile and engage in pro-organizational behavior (Stamper et al., 2009; Turnley and Feldman, 1999). Being a type of pro- and anti-organizational behavior (Van Dyne and LePine, 1998), employees are more likely to refrain from voice and engage in silence when their needs are not fulfilled (Morrison, 2014). Similarly, positive work environments, consisting of sufficient job resources, should contribute to employee voice and inhibit employee silence (for a meta-analysis see $\mathrm{Ng}$ and Feldman, 2015). In those weeks that job insecurity thwarts employees' need fulfilment, important job resources are lacking (see e.g. Breevaart, Bakker, Demerouti, Sleebos and Maduro, 2014; Van den Broeck et al., 2008) and the work environment can hardly be considered positive. Following this reasoning, we expect that employees will engage in less voice and more silence in those weeks that their basic need fulfilment is thwarted.

The abovementioned reasoning assumes that voice and silence are prosocially motivated, that is, employees engage in or refrain from voice and silence depending on their relationship with others (e.g. coworkers, supervisor, organization). Ng and Feldman (2015) argue that there is another, complementary perspective, which is that voice and silence can be self-directed (Bolino et al., 2004; Van Dyne et al., 2003). That is, voice and silence are a way to regulate one's personal resources. People are motivated to protect, maintain and obtain resources, such as time and energy, because losing such valued resources is stressful (Brotheridge and Lee, 2002; Hobfoll, 1989, 2002). In stressful situations, such as those that thwart individuals' need fulfilment (Van den Broeck et al., 2008), employees may engage in silence and refrain from voice to protect their personal resources. That is, challenging the status quo requires resources such as time and energy (i.e. communicating your idea, defending it, and dealing with counterarguments), and there may not be an immediate return on investment. In line with the idea that voice requires resources, Bolino and Turnley (2005) found that personal initiative is positively associated with higher levels of job stress. Thus, to protect their personal resources, employees may refrain from voice and engage in silence in those weeks that job insecurity thwarts their basic need fulfilment. To date, two between-person studies examined need fulfilment to explain the effects of job insecurity on organizational behaviors, showing that need frustration mediates the relation between job insecurity and well-being (Vander Elst et al., 2012) and between job insecurity and counterproductive work behavior (Van den Broeck et al., 2014). Following these previous findings and our theoretical arguments, we propose the following two hypotheses:

H1. Weekly job insecurity is indirectly related to weekly voice via weekly need fulfilment. That is, in those weeks in which job insecurity is higher, employees' need fulfilment is thwarted, and therefore, employees are less likely to voice.

H2. Weekly job insecurity is indirectly related to weekly silence via weekly need fulfilment. That is, in those weeks in which job insecurity is higher, employees' need fulfilment is thwarted, and therefore, employees are more likely to be silent.

\section{Method}

\section{Participants and procedure}

The study was conducted among employees in various organizations in Chile. All participants were professionals who attended a part-time MBA program offered by one of 
the major universities in the country. Research assistants at the university helped with data collection by distributing paper-and-pencil diary questionnaires to participants. They introduced the project to participants in groups of 15, explained the purpose and value of the study, and highlighted participants' rights to confidentiality and voluntary participation. In all surveys, a cover letter accompanying the questionnaire indicated that the survey was being conducted solely for scientific purposes. The research did not involve any form of deception or risk to the participants beyond that encountered in everyday life and the official research ethics committee of University of Santiago approved our study. A personal identification code was used to allow for linking data across time.

Participants filled out weekly questionnaires on Friday afternoon at the end of the working week for five weeks, when they attended their activities at the university. The analyses were conducted on the participants who filled out at least three weekly questionnaires to ensure that the data were sufficiently representative of weekly variations. The final sample therefore consisted of 97 participants (65.1 percent of the original sample); 45 men (46.4 percent) and 51 women (52.6 percent; one participant did not indicate his/her gender). The age of participants ranged between 22 and 49 years, with an average age of 31.30 years $(\mathrm{SD}=6.35)$. Out of all the participants, 13.4 percent worked on an administrative level, 42.3 percent had technician positions, 11.3 percent were professionals, 6.2 percent were supervisors, 3.1 percent were managers and 14.4 percent were executives. Regarding the educational level of the participants, 1 percent of them had a maximum of high school education, 1 percent had completed technical education, 43.3 percent had undergraduate training and 48.5 percent finished postgraduate studies. The mean organizational tenure was 5.11 years $(\mathrm{SD}=4.90)$, varying from a minimum of one month to a maximum of 22 years.

\section{Measures}

Following Brislin's (1970) translation-back translation procedure, two of the authors independently translated and back translated all the measures used in this study between English and Spanish. In cases of translation discrepancies, the two translators discussed the implications of these differences and decided on a final version of the respective item together. All following measures used a five-point Likert scale ranging from 1 - strongly disagree to 5 - strongly agree.

Job insecurity was measured with the four-item scale from De Witte (2000). Items were adapted such that they reflected the experiences of employees during the particular week they looked back upon. An example item is: "This week, I worried about losing my job." The $\alpha$ reliability ranged from 0.83 to 0.91 across weeks.

Basic need fulfilment: the Work-Related Basic Needs Satisfaction Scale (Van den Broeck et al., 2010) was used to measure basic need fulfilment. This scale measures the need for autonomy (e.g. "This week, I felt free to do my job the way I think it could best be done."), the need for competence (e.g. "This week, I felt competent at my job."), and the need for relatedness (e.g. "This week, I did not really feel connected with other people at my job.") with three items each. This scale had good $\alpha$ reliability, ranging from 0.72 to 0.84 across weeks.

Voice was measured with three items of the prosocial voice scale (Van Dyne et al., 2003). The scale had good $\alpha$ reliability (ranging from 0.70 to 0.90 ) and consisted of items such as: "This week, I suggested ideas for change, based on constructive concern for the organization."

Silence was measured with the five-item scale from Detert and Edmondson (2011). An example item is: "This week, I withheld ideas from my boss for changing inefficient work policies." In our questionnaire, we included three items that had a good $\alpha$ reliability, ranging from 0.88 to 0.90 across weeks. 


\section{CDI}

Negative affect was measured as a control variable using the six-item scale for the multiaffect indicator (Warr and Parker, 2010). Participants rated how often they had felt depressed, anxious, dejected, worried, despondent and tense during the last week. $\alpha$ 's ranged from 0.75 to 0.85 across weeks.

\section{Analytical strategy}

We tested our measurement model and indirect effects model using latent variables with structural equation modeling in Mplus (Muthén and Muthén, 1998 -2015). Our data have a nested structure, with weeks $(n=3.65$ weeks on average $\times 97$ persons $=354$ data points) nested in persons $(n=97)$. We used the TYPE $=$ COMPLEX option in Mplus to account for the non-independence of observations and analyze our data on the week level. We calculated the intra-class correlations (ICCs) to examine the variance of our study variables at the within-person (i.e. week) level by dividing the between-person variance by the sum of the between- and within-person variance. The ICC values reflect how much variance in each variable is attributable to differences between individuals, and subtracting the ICC-values from 1 reflects the amount of variance attributable to intra-individual differences for each variable. The ICCs showed that around half of the variance in our study variables was explained at the within-person level: 50.92 percent in negative affect, 47.78 percent in job insecurity, 39.63 percent in need fulfilment, 56.03 percent in silence and 52.87 percent in voice.

\section{Results}

Descriptive statistics, correlations and variance components

Table I shows the means, standard deviations and within-person correlations between the control variable (i.e. negative affect) and the study variables. We controlled for weekly negative affect because in the weeks in which participants experience more negative affect, they may report higher levels of job insecurity (De Witte, 2005) and silence, and lower need fulfilment and voice compared to weeks in which they experience less negative affect.

\section{Measurement model}

First, we tested the measurement model, consisting of our four study variables (i.e. weekly job insecurity, need fulfilment, voice and silence), and our control variable (i.e. negative affect). Accordingly, our measurement model included five latent variables and their indicators; job insecurity (four items), need fulfilment (three dimensions: need for autonomy, need for competence, and need for relatedness), voice (three items), silence (three items), and

Table I.

Means, standard deviations, ICC's, within-week level inter-correlations and internal consistencies (Cronbach's $\alpha$ s on the diagonal) between the study variables

\begin{tabular}{|c|c|c|c|c|c|c|c|c|}
\hline & $M$ & SD & $\begin{array}{c}1-\mathrm{ICC} \\
(\%)\end{array}$ & 1. & 2. & 3. & 4. & 5. \\
\hline $\begin{array}{l}\text { 1. Weekly negative } \\
\text { affect }\end{array}$ & 2.324 & 0.738 & 50.92 & $\begin{array}{c}(0.754- \\
0.850)\end{array}$ & & & & \\
\hline $\begin{array}{l}\text { 2. Weekly job } \\
\text { insecurity }\end{array}$ & 1.822 & 0.908 & 47.78 & $0.411^{* * * *}$ & $\begin{array}{c}(0.830- \\
0.907)\end{array}$ & & & \\
\hline $\begin{array}{l}\text { 3. Weekly need } \\
\text { fulfilment }\end{array}$ & 3.944 & 0.614 & 39.63 & $-0.531^{* * * *}$ & $-0.347^{* * * *}$ & $\begin{array}{c}(0.724- \\
0.835)\end{array}$ & & \\
\hline 4. Weekly voice & 3.779 & 0.823 & 52.87 & -0.153 & -0.041 & $0.579 * * *$ & $\begin{array}{c}(0.702- \\
0.902)\end{array}$ & \\
\hline 5. Weekly silence & 2.321 & 0.949 & 56.03 & $0.359^{* * * *}$ & 0.155 & $-0.434^{* * * *}$ & $-0.267 * *$ & $\begin{array}{c}(0.875- \\
0.895)\end{array}$ \\
\hline
\end{tabular}

Notes: $n=97$ persons and $n=354$ weeks. $1-$ ICC refers to the percentage of within-person variance observed in that variable. ${ }^{*} p<0.05 ; * * p<0.01 ; * * p<0.001$ 
negative affect (six items). The measurement model fitted the data well $\left(\chi^{2}(142)=320.785\right.$, $\mathrm{CFI}=0.922 ; \mathrm{TLI}=0.907, \mathrm{RMSEA}=0.060 ; \mathrm{SRMR}=0.063)$ and all indicators loaded significantly onto their intended latent factors $(p<0.01)$. Next, we performed Harman's single factor test to get an idea of the likelihood of common method variance biasing our results. This single factor model consisted of all variables that were included in the measurement model and showed a very poor fit to our data $\left(\chi^{2}(152)=1,938.215\right.$, $\mathrm{CFI}=0.224$; TLI $=0.127$, RMSEA $=0.182$; SRMR $=0.151$ ). Based on this test, it is unlikely that common method has biased our results. Finally, we tested a model in which voice and silence (reversed scores) were combined into one model, which did not fit the data well and therefore further supported the distinctiveness of these two constructs $\left(\chi^{2}(146)=761.467\right.$, $\mathrm{CFI}=0.733 ; \mathrm{TLI}=0.687, \mathrm{RMSEA}=0.109 ; \mathrm{SRMR}=0.111$ ).

\section{Indirect effects hypotheses}

We tested two different models (see Table II). First, we tested our indirect effects hypotheses while controlling for weekly negative affect (M0). In the second model (M1), we added the direct effects from weekly job insecurity to weekly voice and silence and compared the fit of both models. $H 1$ and $H 2$ state that weekly voice $(H 1)$ and silence $(H 2)$ are indirectly related to weekly job insecurity through weekly need fulfillment. We estimated a latent structural equation model to test these hypotheses simultaneously. First, weekly job insecurity was negatively related to weekly need fulfilment $\left(b^{*}=-0.323, \mathrm{SE}=0.096, p<0.001,95 \% \mathrm{CI}\right.$ $[-0.481,-0.165])$. Next, weekly need fulfilment was positively related to voice $\left(b^{*}=0.560\right.$, $\mathrm{SE}=0.067, p<0.001,95 \% \mathrm{CI}[0.450,0.671])$ and negatively related to silence $\left(b^{*}=-0.435\right.$, $\mathrm{SE}=0.073, p<0.001,95 \% \mathrm{CI}[-0.555,-0.315])$. In addition, we found support for the two indirect effects. Weekly need fulfilment explains the relation between weekly job insecurity on the one hand and silence $\left(b^{*}=0.140, \mathrm{SE}=0.048, p<0.01,95 \% \mathrm{CI}[0.061,0.220]\right)$ and voice $\left(b^{*}=-0.181, \mathrm{SE}=0.052, p<0.001,95 \% \mathrm{CI}[-0.266,-0.096]\right)$ on the other hand. That is, employees' need fulfilment is thwarted in the weeks that employees experience more job insecurity, which in turn is associated with less voice and more silence. Our indirect effects model fitted well to the data $\left(\chi^{2}(144)=326.281, \mathrm{CFI}=0.921\right.$; TLI $=0.906$, RMSEA $=0.060$; $\mathrm{SRMR}=0.069)$ and explained 10.4 percent of the variance in weekly need fulfilment, 31.4 percent in weekly voice, and 18.9 percent in weekly silence.

We also tested a model including the direct effects from job insecurity to employee voice and silence and compared the fit of this model to the model without the direct effects. We found that job insecurity was unrelated to both employee voice $\left(b^{*}=0.137, \mathrm{SE}=0.071\right.$, $p=0.052)$, and silence $\left(b^{*}=-0.045, \mathrm{SE}=0.097, p=0.322\right)$. Additionally, both indirect effects became non-significant after including the direct effects from weekly job insecurity to weekly voice and silence (see Table II). Next, we compared the fit of the model including the direct effects (M1) to the model excluding the direct effects (M0). We used the -2Loglikelihood difference test to assess the fit of our models (please see Satorra and Bentler, 1999, for the formulas to compute the chi-square difference test based on the log-likelihood values and scaling correction factors in Mplus). The results showed that there was a nonsignificant increase in fit for the model including the direct effects compared to the null model excluding the direct effects from job insecurity to employee voice and silence $(\Delta-2 \log$-likelihood $(2)=5.141 ; p=0.076)$. Therefore, and because job insecurity was not significantly related to voice and silence directly, we preferred our hypothesized, more parsimonious model. Figure 1 represents our final indirect effects model.

\section{Additional analyses}

Although we were interested in immediate, same week effects, we also examined lagged effects to further explore the causal order of our indirect effects model. That is, we created lagged variables for need fulfilment, voice, and silence to examine the effects of weekly job 

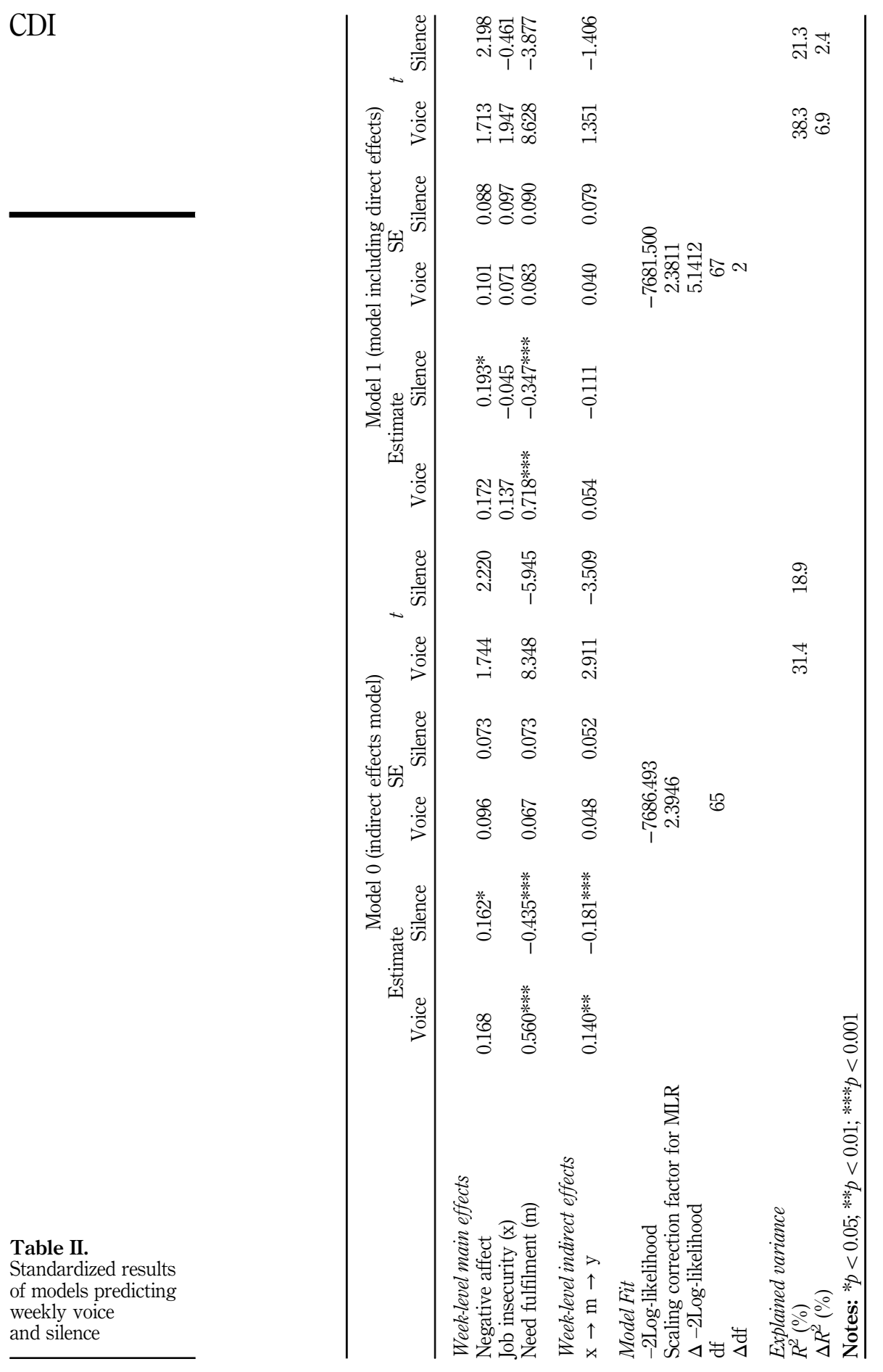

Table II.

Standardized results of models predicting weekly voice and silence 
Our study focused on the dynamic part of job insecurity. That is, similar to the study by Schreurs et al. (2012), we showed that the same employee may worry more or less about losing his/her job from week to week. Schreurs et al. (2012) showed that in those weeks that employees felt more insecure about their job, their in-role performance suffered, but when employees received social support from their supervisor, this detrimental effect was reduced. Our goal was to better understand the dynamic nature of job insecurity and its short-term consequences, which is why we examined how weekly intra-individual fluctuations in job insecurity were related to employee voice and silence, as explained by the fulfilment of employees' basic needs. Specifically, we argued that weekly feelings of job insecurity as a job stressor would thwart employees' basic need fulfilment and employees would consequently engage in less voice and more silence in these weeks. Our results generally supported our hypothesized model.

\section{Theoretical implications}

Most studies on job insecurity focus on between person differences in job insecurity, showing that some employees worry more about losing their job than others, which has various negative effects, such as reduced commitment to the organization and job performance, and increased turnover intentions (Cheng and Chan, 2008; Shoss, 2017; Sverke et al., 2002). Additionally, between-level studies show that employees who feel more insecure about their job show reduced well-being (Vander Elst et al., 2012) and increased counterproductive work behavior (Van den Broeck et al., 2014), because their needs are generally less satisfied. Our study adds to this literature and the nomological network surrounding job insecurity by studying the dynamic nature of job insecurity and by showing that when employees experience more job insecurity, their basic need fulfilment is thwarted, which, in turn, reduces employee voice and increases employee silence in these weeks. Our additional analyses demonstrated that weekly job insecurity was negatively related to the fulfilment of all three different needs. We also found that the lower the fulfilment of the needs for autonomy, competence and relatedness, the more likely it is that employees are silent. Yet, whereas the fulfilment of the need for autonomy and the need for competence increased employees' likelihood to voice on a weekly basis, the fulfilment of the need for relatedness was unrelated to employee voice. We can only cautiously interpret this finding, considering that we did not hypothesize effects for the different needs and that we may lack the power to estimate a model including three mediators and two outcome variables. Yet, one possible explanation could be that reasons to engage in voice are more individualistic and less dependent on colleagues, although one could also argue that voice behaviors are risky and therefore require the feeling of support from important others such as colleagues. Interestingly, Tangirala et al. (2013) showed that whether or not employees voiced depended on the extent to which employees prioritize the interest of the group (i.e. high duty orientation) or their self-interest (i.e. high achievement orientation), with the former being more likely and the latter being less likely to engage in voice. This suggests that the extent to which voice is prosocially motivated depends on individual differences such as duty and achievement orientation, which may explain the non-significant weekly relation between employees' fulfillment of their need for relatedness and voice.

Our study, together with the study by Schreurs et al. (2012), is among the first to show that job insecurity does not only have long-term but also short-term negative effects (Sverke et al., 2002). That is, we showed that the extent to which employees feel that their job is at risk fluctuates from week to week and accordingly, has different effects depending on feelings and perceptions in those weeks. In the weeks that employees felt that their job was more at risk, they also experienced less need fulfilment and consequently, shared less information with others to bring about positive change (i.e. voice) and more actively 
withheld information (i.e. silence). Thus, our study shows that despite the actual risk of losing one's job, the feeling that one's job is at risk can have serious consequences as well. That is, organizations suffer when employees are silent and do not voice, because voice improves learning and performance and silence causes dissatisfaction and stress, and has even been associated with large scale organizational failures (see Morrison, 2014).

Between-level studies on the relation between job insecurity and employee voice yielded inconsistent results, with some studies showing that job insecurity reduces voice (Berntson et al., 2010; Schreurs et al., 2015), some showing that job insecurity increases employee voice (Sverke and Hellgren, 2001) and others showing that there is no direct relation at all (Sverke and Goslinga, 2003). Our study fits the latter category, as we did not find a direct significant relation between job insecurity and employee voice and silence. We did, however, find indirect effects, in which job insecurity negatively affected employee voice and positively affected employee silence by thwarting employees need fulfilment. One way to explain the inconsistent findings regarding the relation between general feelings of job insecurity and employee voice, is that there may be different reasons why job insecure employees would voice their ideas and/or withhold important information. On the one hand, one could argue that employees would reduce their efforts at work when they feel insecure about losing their job, because job insecurity thwarts employees' needs and violates social exchange norms (De Witte, 2005). On the other hand, when employees feel insecure about their job, they may be more likely to put more effort into their work in an attempt to secure their position in the organization, and therefore increase the use of voice (Huang et al., 2013; Probst, 2004). To shed more light on how job insecurity affects voice and silence, more research is needed to understand how and when employees decide to (not) engage in voice and silence when they are worried about losing their job. Additionally, it would be interesting to examine whether there are different mechanisms at play that explain employees' decision to voice or be silent on the long and the short run.

In her review, Morrison (2014) states that systematic empirical research on voice and silence is lacking and speculates that increased feelings of job insecurity "[...]will make voice seem more risky and thus strengthen the tendency toward silence." (p. 192). Indeed, we showed that frustrating employees' basic needs, and indirectly, job insecurity, are antecedents of employee voice and silence. Moreover, we show that these effects are immediate; job insecurity thwarts employee needs and consequently, inhibits employee voice and encourages employee silence in that same week and the week after. Studying proximal antecedents of voice and silence is important because it tells us something about how to immediately encourage voice and discourage silence, which may prevent long-term negative consequences, such as acquiescence. Acquiescence is a deep form of silence in which employees feel powerless and have given up hope that voice is beneficial (Pinder and Harlos, 2001). Besides our contribution to the nomological network surrounding voice and silence, we also show that they are two distinct phenomena that should both be studied (Morrison, 2011). That is, not voicing does not automatically imply that employees are silent, because there simply may not be any information to share or withhold. Our data indeed supported this idea, showing that voice and silence did not significantly correlate in the overall model $(r=-0.030, p=0.460)$ and that the study of the antecedents and consequences of both constructs is important.

\section{Practical implications}

Our study shows that when employees are less worried about losing their job in the future, their needs are more fulfilled, and consequently, they will engage in more voice and less silence. Importantly, these feelings differ not only between employees, but also within the same employee on a weekly basis. Thus, when employees feel temporarily more insecure about keeping their job in the future, they may not use opportunities to voice and may 
decide to actively withhold important information at that moment. Accordingly, managers should reduce feelings of job insecurity whenever possible to increase employees' feelings over predictability of and control over their future. In this way, employees will feel more autonomous, effective, and connected, which, in turn, increases the likelihood that they will engage in voice and refrain from silence. Based on our results, if managers invest in reducing feelings of job insecurity on a weekly basis, they will receive an immediate return on investment because employees will engage in more voice and be less silent in the week that their needs are more fulfilled after experiencing less job insecurity.

\section{Strengths, limitations and future research}

Our weekly diary study allowed us to examine the short-term effects of job insecurity on voice and silence and one of the underlying processes in its natural context (i.e. at work). Because we measured employees' experiences and behaviors closely after they happened (i.e. at the end of the workweek), we reduced the impact of recall bias on our results and increased the ecological validity of our findings (Ohly et al., 2010; Schwarz, 2012). We consciously decided to use self-reports, because we were interested in mainly private experiences (i.e. experienced job insecurity, need fulfilment, silence) that are difficult for other sources (e.g. supervisors) to report. To reduce the impact of common method bias (Podsakoff et al., 2003), future research could however use supervisor and/or colleague ratings of employee voice.

We proposed two possible explanations for the relation between the lack of need fulfilment on the one hand and employee voice and silence on the other hand. First, we argued that voice and silence are prosocially motivated (i.e. employees' willingness) and second, we argued that voice and silence are self-directed and may be a way for employees to regulate their personal resources (i.e. employees' ability). This duality of pro-voice and anti-silence motives is also found in the existing literature. That is, employees who, for example, have a higher sense of obligation (Liang et al., 2012), higher organizational identification (Liu et al., 2010), and customer orientation (Lam and Mayer, 2014) are more likely to engage in voice. Yet, research also shows that employees who have self-protective implicit voice theories are more likely to be silent (Detert and Edmondson, 2011). From the current study, we cannot conclude whether voice and silence were either prosocially motivated, self-directed, or both, but we believe that this is an interesting venue for future research. Whether voicing is pro-socially or pro-selfmotivated may, for example, be dependent on the content of the voice message and/or the recipient of the voice message.

$\mathrm{Ng}$ and Feldman (2015) argued that stressful situations may encourage employees to conserve their resources, but also to acquire resources to buffer the stress effects. Specifically, this would mean that employees engage in voice and refrain from silence, because this may result in additional resources (e.g. asking for additional resources to alleviate problems). Although our results provide support for the resource conservation hypothesis - i.e., lack of need fulfilment reduced voice and increased silence - future research could contribute to the literature on voice and silence by further exploring these theoretical explanations. For example, whether employees will engage in voice and silence under stressful situations may depend on their resource pool at that moment. Another possibility is that the investment of resources in voice is dependent on the expected return on investment. Research has shown that employees are more likely to engage in voice when they have a higher sense of psychological safety (Detert and Burris, 2007; Detert and Trevino, 2010; Liang et al., 2012), which indicates that employees may fear that there are negative consequences to voice. If these are employees' beliefs, it seems likely that they will not expect to gain resources from engaging in voice. In support of this claim, Detert and Edmondson (2011) found that employees' implicit voice theories were predictive of workplace silence. 


\section{References}

Baumeister, R.F. and Leary, M.R. (1995), "The need to belong: desire for interpersonal attachments as a fundamental human motivation", Psychological Bulletin, Vol. 117 No. 3, pp. 487-529.

Berntson, E., Näswall, K. and Sverke, M. (2010), "The moderating role of employability in the association between job insecurity and exit, voice, loyalty and neglect", Economic and Industrial Democracy, Vol. 31 No. 2, pp. 215-230.

Bolger, N., Stadler, G. and Laurenceau, J.P. (2012), "Power analysis for intensive longitudinal studies", in Mehl, M.R. and Conner, T.S. (Eds), Handbook of Research Methods for Studying Daily Life, Guilford Press, New York, NY, pp. 285-301.

Bolino, M.C. and Turnley, W.H. (2005), "The personal costs of citizenship behavior: the relationship between individual initiative and role overload, job stress, and work-family conflict", Journal of Applied Psychology, Vol. 90 No. 4, pp. 740-748.

Bolino, M.C., Turnley, W.H. and Niehoff, B.P. (2004), "The other side of the story: reexamining prevailing assumptions about organizational citizenship behavior", Human Resource Management Review, Vol. 14 No. 2, pp. 229-246.

Brashers, D.E. (2001), "Communication and uncertainty management", Journal of Communication, Vol. 51 No. 3, pp. 477-497.

Breevaart, K. and Tims, M. (2019), "Crafting social resources on days when you are emotionally exhausted: the role of job insecurity", Journal of Occupational and Organizational Psychology, Vol. 92, pp. 806-824.

Breevaart, K. and Zacher, H. (2019), "Daily SOC strategy use and innovative performance: the role of job autonomy and time pressure”, Journal of Personnel Psychology, Vol. 18 No. 2, pp. 71-83.

Breevaart, K., Bakker, A.B., Demerouti, E., Sleebos, D.M. and Maduro, V. (2014), "Uncovering the underlying relationship between transformational leaders and followers' task performance", Journal of Personnel Psychology, Vol. 13 No. 4, pp. 194-203.

Brislin, R.W. (1970), "Back-translation for cross-cultural research”, Journal of Cross-cultural Psychology, Vol. 1 No. 3, pp. 185-216.

Brotheridge, C.M. and Lee, R.T. (2002), "Testing a conservation of resources model of the dynamics of emotional labor", Journal of Occupational Health Psychology, Vol. 7 No. 1, pp. 57-67.

Cheng, G.H.L. and Chan, D.K.S. (2008), "Who suffers more from job insecurity? A meta-analytic review”, Applied Psychology, Vol. 57 No. 2, pp. 272-303, doi: 10.1111/j.1464-0597.2007.00312.x.

De Witte, H. (2000), “Arbeidsethos en jobonzekerheid: meting en gevolgen voor welzijn, tevredenheid en inzet op het werk", in Bouwen, R., De Witte, K., De Witte, H. and Taillieu, T. (Eds), Van Groep tot Gemeenschap, Garant, Leuven, pp. 325-350.

De Witte, H. (2005), "Job insecurity: review of the international literature on definitions, prevalence, antecedents, and consequences", South African Journal of Industrial Psychology, Vol. 31 No. 4, pp. 1-6.

De Witte, H., Vander Elst, T. and De Cuyper, N. (2015), "Job insecurity, health and well-being”, in Vuori, J., Blonk, R. and Price, R. (Eds), Sustainable Working Lives. Aligning Perspectives on Health, Safety and Well-Being, Springer, Dordrecht.

Debus, M.E., König, C.J. and Kleinmann, M. (2014), "The building blocks of job insecurity: the impact of environmental and person-related variables on job insecurity perceptions", Journal of Occupational and Organizational Psychology, Vol. 87 No. 2, pp. 329-351.

deCharms, R. (1968), Personal Causation, Academic, New York, NY.

Deci, E.L. and Ryan, R.M. (2000), "The 'what' and 'why' of goal pursuits: human needs and the self-determination of behaviour", Psychological Inquiry: An International Journal for the Advancement of Psychological Theory, Vol. 11 No. 4, pp. 227-268.

De Cuyper, N., M€akikangas, A., Kinnunen, U., Mauno, S. and De Witte, H. (2012), “Cross-lagged associations between perceived employability, job insecurity, and exhaustion: testing gain and loss spirals according to the conservation of resources theory", Journal of Organizational Behavior, Vol. 33, pp. 770-788, available at: https://doi.org/10.1002/job.1800 
Dekker, S.W.A. and Schaufeli, W.B. (1995), "The effects of job insecurity on psychological health and withdrawal: a longitudinal study", Australian Psychologist, Vol. 30 No. 1, pp. 57-63.

Detert, J.R. and Burris, E.R. (2007), "Leadership behavior and employee voice: is the door really open?", Academy of Management Journal, Vol. 50 No. 4, pp. 869-884.

Detert, J.R. and Edmondson, A.C. (2011), "Implicit voice theories: taken-for-granted rules of self-censorship at work", Academy of Management Journal, Vol. 54 No. 3, pp. 461-488.

Detert, J.R. and Trevino, L.K. (2010), "Speaking up to higher ups: how supervisor and skip-level leaders influence employee voice", Organizational Science, Vol. 21 No. 1, pp. 249-270.

DiFonzo, N. and Bordia, P. (1998), "A tale of two corporations: managing uncertainty during organizational change", Human Resource Management: Published in Cooperation with the School of Business Administration, The University of Michigan and in alliance with the Society of Human Resources Management, Vol. 37 No. 3/4, pp. 295-303.

Farndale, E., Van Ruiten, J., Kelliher, C. and Hope-Hailey, V. (2011), "The influence of perceived employee voice on organizational commitment: an exchange perspective", Human Resource Management, Vol. 50 No. 1, pp. 113-129.

Hobfoll, S.E. (1989), "Conservation of resources: a new attempt at conceptualizing stress", American Psychologist, Vol. 44 No. 3, pp. 513-524.

Hobfoll, S.E. (2002), "Social and psychological resources and adaptation”, Review of General Psychology, Vol. 6 No. 4, pp. 307-324.

Huang, G.H., Zhao, H.H., Niu, X.Y., Ashford, S.J. and Lee, C. (2013), "Reducing job insecurity and increasing performance ratings: does impression management matter?", Journal of Applied Psychology, Vol. 98 No. 5, pp. 852-862, doi: 10.1037/a0033151.

Jahoda, M. (1981), "Work, employment, and unemployment: values, theories, and approaches in social research”, American Psychologist, Vol. 36, pp. 184-191.

Jiang, L. and Lavaysse, L.M. (2018), "Cognitive and affective job insecurity: a meta-analysis and a primary study”, Journal of Management, Vol. 44 No. 6, pp. 2307-2342.

Lam, C.F. and Mayer, D.M. (2014), "When do employees speak up for their customers? A model of voice in a customer service context", Personnel Psychology, Vol. 67 No. 3, pp. 637-666, doi: 10.1111/ peps.12050.

Låstad, L., Berntson, E., Näswall, K. and Sverke, M. (2014), "Do core self-evaluations and coping style influence the perception of job insecurity?", European Journal of Work and Organizational Psychology, Vol. 23 No. 5, pp. 680-692, doi: 10.1080/1359432X.2013.800678.

Latack, J.C. and Dozier, J.B. (1986), “After the ax falls: job loss as a career transition”, Academy of Management Review, Vol. 11 No. 2, pp. 375-392.

Liang, J., Farh, C.I.C. and Farh, J.L. (2012), "Psychological antecedents of promotive and prohibitive voice: a two-wave examination", Academy of Management Journal, Vol. 55 No. 1, pp. 71-92.

Liu, W., Zhu, R. and Yang, Y. (2010), "I warn you because I like you: voice behavior, employee identifications, and transformational leadership", Leadership Quarterly, Vol. 21 No. 1, pp. 189-202.

Mauno, S., De Cuyper, N., Tolvanen, A., Kinnunen, U. and Mäkikangas, A. (2014), "Occupational well-being as a mediator between job insecurity and turnover intention: findings at the individual and work department levels", European Journal of Work and Organizational Psychology, Vol. 23 No. 3, pp. 381-393, doi: 10.1080/1359432X.2012.752896.

Morrison, E.W. (2011), "Voice and silence within organizations: literature review and directions for future research", Academy of Management Annuals, Vol. 5 No. 1, pp. 373-412.

Morrison, E.W. (2014), "Employee voice and silence", Annual Review of Organizational Psychology and Organizational Behavior, Vol. 1 No. 1, pp. 173-197.

Morrison, E.W. and Milliken, F.J. (2000), "Organizational silence: a barrier to change and development in a pluralistic world", Academy of Management Review, Vol. 25 No. 4, pp. 706-725.

Muthén, L.K. and Muthén, B.O. (1998-2015), Mplus User's Guide, 7th ed., Muthén \& Muthén, Los Angeles, CA. 
Ng, T.W. and Feldman, D.C. (2015), "Idiosyncratic deals and voice behavior", Journal of Management, Vol. 41 No. 3, pp. 893-928, doi: 10.1177/0149206312457824.

Nikolaou, I., Vakola, M. and Bourantas, D. (2008), "Who speaks up at work? Dispositional influences on employees' voice behavior”, Personnel Review, Vol. 37 No. 6, pp. 666-679.

Ohly, S., Sonnentag, S., Niessen, C. and Zapf, D. (2010), "Diary studies in organizational research: an introduction and some practical recommendations", Journal of Personnel Psychology, Vol. 9 No. 2, pp. 79-93.

Pinder, C.C. and Harlos, K.P. (2001), "Employee silence: quiescence and acquiescence as responses to perceived injustice", Research on Personality and Human Resource Management, Vol. 20, pp. 331-369.

Podsakoff, P.M., MacKenzie, S.B., Lee, J. and Podsakoff, N.P. (2003), "Common method biases in behavioral research: a critical review of literature and recommended remedies", Journal of Applied Psychology, Vol. 88 No. 5, pp. 879-903.

Probst, T.M. (2004), "Safety and insecurity: exploring the moderating effect of organizational safety climate", Journal of Occupational Health Psychology, Vol. 9 No. 1, pp. 3-10, doi: 10.1037/ 1076-8998.9.1.3.

Satorra, A. and Bentler, P.M. (1999), "A scaled difference chi-square test statistic for moment structure analysis”, Psychometrika, Vol. 66 No. 4, pp. 507-514.

Schreurs, B., Günter, H., Jawahar, I.J. and De Cuyper, N. (2015), "Speaking up when feeling job insecure: the moderating role of punishment and reward sensitivity", Journal of Organizational Change Management, Vol. 28 No. 6, pp. 1107-1128.

Schreurs, B., Hetty van Emmerik, I.J., Günter, H. and Germeys, F. (2012), "A weekly diary study on the buffering role of social support in the relationship between job insecurity and employee performance", Human Resource Management, Vol. 51 No. 2, pp. 259-279.

Schwarz, N. (2012), "Why researchers should think 'real-time'”, in Mehl, M.R. and Conner, T.A. (Eds), Handbook of Research Methods for Studying Weekly Life, Guilford Press, New York, NY, pp. 144-159.

Shoss, M. (2017), "Job insecurity: an integrative review and agenda for future research", Journal of Management, Vol. 43 No. 6, pp. 1911-1939.

Stamper, C.L., Masterson, S.S. and Knapp, J. (2009), "A typology of organizational membership: understanding different membership relationships through the lens of social exchange", Management and Organization Review, Vol. 5 No. 3, pp. 303-328, doi: 10.1111/j.17408784.2009.00147.x.

Sverke, M. and Goslinga, S. (2003), "The consequences of job insecurity for employers and unions: exit, voice and loyalty", Economic and Industrial Democracy, Vol. 24 No. 2, pp. 241-270.

Sverke, M. and Hellgren, J. (2001), "Exit, voice and loyalty reactions to job insecurity in Sweden: do unionized and non-unionized employees differ?", British Journal of Industrial Relations, Vol. 39 No. 2, pp. 167-182.

Sverke, M., Hellgren, J. and Näswall, K. (2002), "No security: a meta-analysis and review of job insecurity and its consequences", Journal of Occupational Health Psychology, Vol. 7 No. 3, pp. 242-264.

Sverke, M., Låstad, L., Hellgren, J., Richter, A. and Näswall, K. (2019), “A meta-analysis of job insecurity and employee performance: testing temporal aspects, rating source, welfare regime, and union density as moderators", International Journal of Environmental Research and Public Health, Vol. 16 No. 14, pp. 2536-2565.

Tangirala, S., Kamdar, D., Venkataramani, V. and Parke, M.R. (2013), "Doing right versus getting ahead: the effects of duty and achievement orientations on employees' voice", Journal of Applied Psychology, Vol. 98 No. 6, pp. 1040-1050.

Turnley, W.H. and Feldman, D.C. (1999), "The impact of psychological contract violations on exit, voice, loyalty, and neglect", Human Relations, Vol. 52 No. 7, pp. 895-922. 
Van den Broeck, A., Vansteenkiste, M., De Witte, H. and Lens, W. (2008), "Explaining the relationships between job characteristics, burnout, and engagement: the role of basic psychological need satisfaction", Work \& Stress, Vol. 22 No. 3, pp. 277-294.

Van den Broeck, A., Vansteenkiste, M., De Witte, H., Soenens, B. and Lens, W. (2010), "Capturing autonomy, competence, and relatedness at work: construction and initial validation of the workrelated basic need satisfaction scale", Journal of Occupational and Organizational Psychology, Vol. 83 No. 4, pp. 981-1002.

Van den Broeck, A., Sulea, C., Vander Elst, T., Fischmann, G., Iliescu, D. and De Witte, H. (2014), "The mediating role of psychological needs in the relation between qualitative job insecurity and counterproductive work behavior", Career Development International, Vol. 19 No. 5, pp. 526-547.

Van Dyne, L.V. and LePine, J.A. (1998), "Helping and voice extra-role behavior: evidence of construct and predictive validity", Academy of Management Journal, Vol. 41 No. 1, pp. 108-119.

Van Dyne, L.V., Ang, S. and Botero, I.C. (2003), "Conceptualizing employee silence and employee voice as multidimensional constructs", Journal of Management Studies, Vol. 40 No. 6, pp. 1359-1392.

Van Hooff, M.L. and Geurts, S.A. (2014), "Need satisfaction during free evening hours: examining its role in daily recovery", Stress and Health, Vol. 30 No. 3, pp. 198-208.

Vander Elst, T., Van den Broeck, A., De Witte, H. and De Cuyper, N. (2012), "The mediating role of frustration of psychological needs in the relationship between job insecurity and work-related well-being", Work \& Stress, Vol. 26 No. 3, pp. 252-271.

Verstuyf, J., Vansteenkiste, M., Soenens, B., Boone, L. and Mouratidis, A. (2013), "Daily ups and downs in women's binge eating symptoms: the role of basic psychological needs, general self-control, and emotional eating", Journal of Social and Clinical Psychology, Vol. 32 No. 3, pp. 335-361.

Warr, P. and Parker, S.K. (2010), "IWP multi-affect indicator", unpublished instrument, Institute of Work Psychology, University of Sheffield, Sheffield.

Weinberger, E., Wach, D., Stephan, U. and Wegge, J. (2018), "Having a creative day: Understanding entrepreneurs' daily idea generation through a recovery lens", Journal of Business Venturing, Vol. 33 No. 1, pp. 1-19.

White, R.W. (1959), "Motivation reconsidered: the concept of competence", Psychological Review, Vol. 66 No. 5, pp. 297-333.

\section{Further reading}

Ashford, S.J., Sutcliffe, K. and Christianson, M.K. (2009), "Speaking up and speaking out: the leadership dynamics of voice in organizations", in Edwards, M.S. and Greenberg, J. (Eds), Voice and Silence in Organizations, Emerald Group, Bingley, pp. 175-201.

Barnes, C.M., Lucianetti, L., Bhave, D.P. and Christian, M.S. (2015), “'You wouldn’t like me when I'm sleepy': leaders' sleep, daily abusive supervision, and work unit engagement”, Academy of Management Journal, Vol. 58 No. 5, pp. 1419-1437.

Bolger, N., Davis, A. and Rafaeli, E. (2003), "Diary methods: capturing life as it is lived”, Annual Review of Psychology, Vol. 54 No. 1, pp. 579-616.

Breevaart, K., Bakker, A., Hetland, J., Demerouti, E., Olsen, O.K. and Espevik, R. (2014), "Daily transactional and transformational leadership and daily employee engagement", Journal of Occupational and Organizational Psychology, Vol. 87 No. 1, pp. 138-157.

Cropanzano, R. and Mitchell, M.S. (2005), "Social exchange theory: an Interdisciplinary review", Journal of Management, Vol. 31 No. 6, pp. 874-900.

De Cuyper, N. and DeWitte, H. (2005), "Job insecurity: mediator or moderator of the relationship between type of contract and various outcomes", South African Journal of Industrial Psychology, Vol. 31 No. 4, pp. 79-86. 
Deci, E.L. and Ryan, R.M. (2008), "Facilitating optimal motivation and psychological well-being across life's domains", Canadian Psychology/Psychologie Canadienne, Vol. 49 No. 1, pp. 14-23.

Detert, J.R., Burris, E.R. and Harrison, D.A. (2010), "Debunking four myths about employee silence", Harvard Business Review, Vol. 8 No. 6, p. 26.

Gunthert, K.C. and Wenze, S.J. (2012), "Weekly diary methods", in Mehl, M.R. and Conner, T.A. (Eds), Handbook of Research Methods for Studying Weekly Life, Guilford Press, New York, NY, pp. 144-159.

Låstad, L., Berntson, E., Näswall, K., Lindfors, P. and Sverke, M. (2015), "Measuring quantitative and qualitative aspects of the job insecurity climate: scale validation”, Career Development International, Vol. 20 No. 3, pp. 202-217.

Milliken, F.J., Morrison, E.W. and Hewlin, P. (2003), “An exploratory study of employee silence: issues that employees don't communicate upward and why", Journal of Management Studies, Vol. 40 No. 6, pp. 1453-1476.

Ng, T.W.H. and Feldman, D.C. (2011), "Employee voice behavior: a meta-analytic test of the conservation of resources framework", Journal of Organizational Behavior, Vol. 33 No. 2, pp. 216-234.

Schwartz, J.E. and Stone, A.A. (1998), "Strategies for analyzing ecological momentary assessment data", Health Psychology, Vol. 17 No. 1, pp. 6-16.

Tims, M., Bakker, A.B. and Xanthopoulou, D. (2011), "Do transformational leaders enhance their followers' daily work engagement?”, The Leadership Quarterly, Vol. 22 No. 1, pp. 121-131.

\section{Corresponding author}

Kimberley Breevaart can be contacted at: breevaart@essb.eur.nl

For instructions on how to order reprints of this article, please visit our website: 